2. https://www.hindustantimes.com/india-news/science-or-sci-fi-the-ignorance-about-dinosaurs-in-india/story-Xz8vEkuJuRzQHfhnQq4FNM. $\underline{\mathrm{html}}$

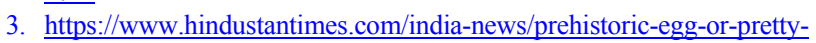
tool-protecting-dinosaur-fossils-in-india/story-XTugah1PglfB6QrEZRMruK.html

4. http://www.sciencemag.org/news/2018/04/india-s-paleontologists-fightdestruction-its-fossil-riches

5. Rajendran, K., Rajendran, C. P., Thakkar, M. and Tuttle, M. P., The 2001 Kutch (Bhuj) earthquake: coseismic surface features and their significance. Curr. Sci., 2001, 80, 1397-1405.

6. EERI, Earthquake Engineering Research Institute Special Earthquake Report, Preliminary observation on the origin and effects of the Jan 26, 2001-Bhuj (Gujarat, India) earthquake. EERI, 2001, pp. 1-16; https://www.istructe.org/downloads/resources-centre/ technical-topic-area/eefit/eefit-reports/bhuj-india.pdf

7. Hounslow, A. W., Water Quality Data Analysis and Interpretation, CRC Press, Florida, USA, 1995.

8. Keesari, T., Shivanna, K. and Jalihal, A. A., Isotope hydrochemical approach to understand fluoride release into groundwaters of Ilkal area, Bagalkot district, Karnataka, India. Hydrogeol. J., 2007, 15, 589-598.

9. Coplen, T. B., New guidelines for reporting stable hydrogen, carbon and oxygen isotope-ratio data. Geochim. Cosmochim. Acta, 1996, 60, 3359-3360.

10. Brian, H., Perkins, E. H. and Gunter, W. D., Introduction to Ground Water Geochemistry, Geoscience Publishing Ltd, Canada, 1999.

11. Keesari, T., Kulkarni, U. P., Deodhar, A., Ramanjaneyulu, P. S., Sanjukta, A. K. and Kumar, U. S., Geochemical characterization of groundwater from an arid region in India. Environ. Earth Sci., 2014, 71(11), 4869-4888.

12. Kinsman, D. J. J., Interpretation of $\mathrm{Sr}^{2+}$ concentrations in carbonate minerals and rocks. J. Sediment. Petrol., 1969, 39, 486508 .

13. Fass, T., Cook, P. G., Stieglitz, T. and Herczeg, A. L., Development of saline groundwater through transpiration of seawater. Ground Water, 2007, 45, 703-710.

14. Warner, N. R. et al., Geochemical evidence for possible natural migration of Marcellus Formation brine to shallow aquifers in Pennsylvania. Proc. Natl. Acad. Sci. USA, 2012, 109(30), 1196111966.

15. Kim, Y. et al., Hydrogeochemical and isotopic evidence of groundwater salinization in a coastal aquifer: a case study in Jeju volcanic island, Korea. J. Hydrol., 2003, 270, 282-294.

16. Mercado, A., The use of hydrogeochemical patterns in carbonate sand and sandstone aquifers to indentify intrusion and flushing of saline water. Groundwater, 1985, 23(5), 635-645.

17. Merh, S. S., Geology of Gujarat, Geological Survey of India, 1995.

18. Pande, J. and Guha, D. K., Termination of last Neogene transgression and some Quaternary shoreline changes in Gujarat. 1st National Seminar on Quat. Envi. Papers (ed. Merh, S. S.), Hindustan Pub Co., Delhi, 1982, pp. 396-412.

19. Merh, S. S. and Chamyal, L. S., The Quaternary sediments in Gujarat. Curr. Sci., 1993, 64, 823-827.

20. Gupta, S. K., Bhandari, N., Thakkar, P. S. and Rengarajan, R., On the origin of the artesian groundwater and escaping gas at Narveri after the 2001 Bhuj earthquake. Curr. Sci., 2002, 82, 463-468.

21. Clark, I. and Fritz, P., Environmental Isotopes in Hydrogeology, Lewis Publ., Boca Raton, FL, USA, 1997, p. 328.

22. Solomon, D. K., Genereux, D. P., Plummer, L. N. and Busenberg, E., Testing mixing models of old and young groundwater in a tropical lowland rainforest with environmental tracers. Water Resour. Res., 2010, 46, W04518; doi:10.1029/2009WR008341.

23. Cook, P. G. and Böhlke, J. K., Determining timescales for groundwater flow and solute transport. In Environmental Tracers in Subsurface Hydrology (eds Cook, P. G. and Herczeg, A.), Kluwer, Boston, Mass., USA, 2000, pp. 1-30.

24. Schlosser, P., Stute, M., Doff, H., Sonntag, C. and Munnich, K. O., Tritium $/{ }^{3} \mathrm{He}$ dating of shallow groundwater. Earth Planet. Sci. Lett., 1988, 89, 352-363; doi:10.1016/0012-821X(88)90122-7.

25. Cook, P. G., Plummer, L. N., Solomon, D. K., Busenberg, E. and Han, L. F., Effects and processes that can modify apparent CFC age. In Use of Chlorofluorocarbons in Hydrology: A Guidebook, International Atomic Energy Agency, Vienna, Austria, 2006, pp. 31-58.

ACKNOWLEDGEMENTS. We thank the staff members of Isotope Hydrology Section, Bhabha Atomic Research Centre, Mumbai and National Dairy Development Board, Gujarat for help during sampling.

Received 23 July 2018; revised accepted 10 February 2019

doi: $10.18520 / \mathrm{cs} / \mathrm{v} 116 / \mathrm{i} 8 / 1407-1410$

\section{Origin and distribution of shallow gas-charged sediment on the inner continental shelf of central west coast of India}

\author{
K. M. Dubey ${ }^{1,2}$ and A. K. Chaubey ${ }^{3, *}$ \\ ${ }^{1}$ CSIR-National Institute of Oceanography, Dona-Paula, \\ Goa 403 004, India \\ ${ }^{2}$ Department of Marine Sciences, Goa University, \\ Taleigao Plateau, Goa 403 206, India \\ ${ }^{3}$ CSIR-National Institute of Oceanography, Regional Centre, \\ Andheri (W), Mumbai 400 053, India
}

High-resolution shallow seismic investigations on inner continental shelf of Goa have been carried out to map gas-charged sediment zones and investigate origin of trapped gas. Analyses of data reveal that the gas is trapped by different stratigraphic layers and is distributed in two zones. Zone- 1 is restricted up to $\sim 30 \mathrm{~m}$ water depth and in the southern part of the study area. In this zone, gas is confined within the Holocene layers above the Holocene maximum Hooding surface (MFS). Whereas, zone-2 is comprised of several isolated gas-charged patches which are distributed in the entire study area mostly between $\sim 20 \mathrm{~m}$ and $\sim 45 \mathrm{~m}$ water depth. In this zone, gas is confined below Holocene-MFS in incised river bed or a layer just below MFS or both. Gas-charged sediment in zone-1 is formed due to degradation of organic material which is predominantly early Holocene mangrove derived, whereas, zone-2 it is formed due to degradation of

*For correspondence. (e-mail: chaubey@nio.org) 
organic material which were deposited by ancestral rivers during the post-glacial sea level rise of the Late Pleistocene. The distribution pattern of zone-1 is controlled by coastline configuration, long-term longshore current pattern, Holocene rapid sea level rise and lithological character of exposed inter-tidal zone. Whereas, distribution of zone-2 is controlled by palaeo-rivers of different glacial periods and their hydraulic energy condition during the base level rise.

Keywords: Acoustic blanking, acoustic turbidity, central west coast of India, gas-charged sediment, mangrove, shallow seismic.

THE number of studies of shallow gas-charged sediment zones has increased over recent decades. One of the main reasons for the growing interest is methane seepage from seabed which alters the surrounding ecosystem and food chain supply system. On a global scale, methane seepage plays an important role in the biogeochemical cycling and elemental transformation of carbon, sulphur and nitrogen ${ }^{1-3}$. Since the gas that escapes from shallow gas-charged sediments is mostly methane, this also contributes to global warming ${ }^{4}$. Therefore, the study of gascharged sediment zones has become important for climate change analysis. For example, methane emitted through gas-charged sediment zones on the continental shelf around the United Kingdom is estimated to contribute $\sim 40 \%$ of the total national emission ${ }^{5}$. Additionally, shallowly trapped gas may also cause sediment instability ${ }^{6}$ which poses hazards to coastal infrastructure.

Shallow gas-charged sediment zones are formed due to microbial methanogenesis of organic material in a sedimentary environment ${ }^{7}$ over thousands of years. Sea level variations during the Late Quaternary changed the sedimentary environment and altered the distribution and quantity of organic matter available at the site, thus providing various types of gas traps ${ }^{7}$. Accumulation of these gases may occur on or beneath the surface of the sedimentary column, as well as in dissolved form in the water column $^{7}$. The shallow gas-charged sediment zones observed in the seismic profile occur in the form of acoustic blanking, acoustic curtains, acoustic columns, acoustic turbidity, turbidity pinnacles and intra-sedimentary plumes $^{8}$.

On the western continental shelf of India, the presence of shallow gas-charged sediments has been reported ${ }^{9-13}$. These gas-charged sediment zones are characterized by acoustic blanking, wipe outs and acoustic turbidity. Methane gas is most abundant in these shallow gascharged sediments ${ }^{11}$. Earlier studies on the western continental shelf of India were based on analysis of either isolated high-resolution shallow seismic profiles or profile lines were taken at coarser spacing (more than 10 nautical miles). Detailed study of these shallow gas features is still lacking on the western continental shelf of India. In this regard, the present study investigates shallow gas- charged sediment zones off Goa, central west coast of India, using closely spaced, high resolution, shallow seismic survey tracks and seeks to discuss origin and factors controlling the distribution pattern of the observed gas-charged sediment zones.

Geographically, the study area is located on the inner continental shelf off Goa, central west coast of India, between lat. $14^{\circ} 43^{\prime} \mathrm{N}$ and $15^{\circ} 38^{\prime} \mathrm{N}$ and long. $73^{\circ} 24^{\prime} \mathrm{E}$ and $74^{\circ} 05^{\prime} \mathrm{E}$ where water depth varies from $\sim 8 \mathrm{~m}$ to $\sim 55 \mathrm{~m}$ (Figure 1). The inner continental shelf is marked by an even and gentle topography with a slope of 1:700 to $1: 3300$ (ref. 14). It is covered by silt and clay up to $\sim 50 \mathrm{~m}$ water depth ${ }^{14}$. A wedge-shaped sediment package on the inner continental shelf off Betul-Karwar is identified $^{13,15,16}$, which is characterized by low amplitude, continuous and parallel reflectors extending seaward ${ }^{13,16}$. This wedge-shaped sediment package thickens towards the shore and pinches out around $50 \mathrm{~m}$ water depth ${ }^{13,15,16}$. Earlier studies have also identified weak reflectors within the wedge, downlapping against a planar surface and referred to the same as maximum flooding surface (Holocene-MFS) ${ }^{13,16}$.

Chapora, Mandovi, Zuari, Sal, Talpona and Galgibag are major estuaries of Goa, which carry terrigenous material from highlands of the Western Ghats and finally debouch in the Arabian Sea. Heavy rainfall in the monsoon season (June-September) on the slopes of the Western Ghats leads to heavy runoff in the catchment area of these estuaries.

The study is primarily based on $\sim 1650$ line kilometre of High-Resolution Shallow Seismic (HRSS) data acquired along 50 parallel track lines with 1 nautical mile line spacing (Figure 1) onboard CRV SagarSukti and MFB Falguni. The data was acquired using a sparker system comprising of energy source CSP D700, multi-tips squid spark array, data acquisition unit Octopus 760 and a 20 element hydrophone array with $0.25 \mathrm{~m}$ hydrophone spacing. Energy source unit was set to supply $300 \mathrm{~J}$ per shot through multi-tipped sparker squid and the seismic signal received through the hydrophone array streamer was recorded at $24 \mathrm{kHz}$ sampling frequency for $500 \mathrm{~ms}$ record length. Each shot was geo-referenced using a differential global positioning system (DGPS).

Acquired data was processed using seismic data processing software package SeisSpace ${ }^{\circledR}$ ProMAX ${ }^{\circledR}$ of Landmark Solutions. The data was re-sampled at $0.1 \mathrm{~ms}$ interval and stored in an internal format of SeisSpace ${ }^{\circledR}$ ProMAX ${ }^{\circledR}$. Re-sampled data was first subjected to trace editing and top muting. Later, it was subjected to bandpass filtering, deconvolution and gain correction to improve seismic reflectors. $P$-wave velocities of $1500 \mathrm{~m} / \mathrm{s}$ for water column and $1583 \mathrm{~m} / \mathrm{s}$ for sedimentary layers were used to convert two-way travel time into depth ${ }^{17}$. The navigation data was extracted from the SEG$\mathrm{Y}$ header of each trace representing a shot point for generating seismic track plot. 


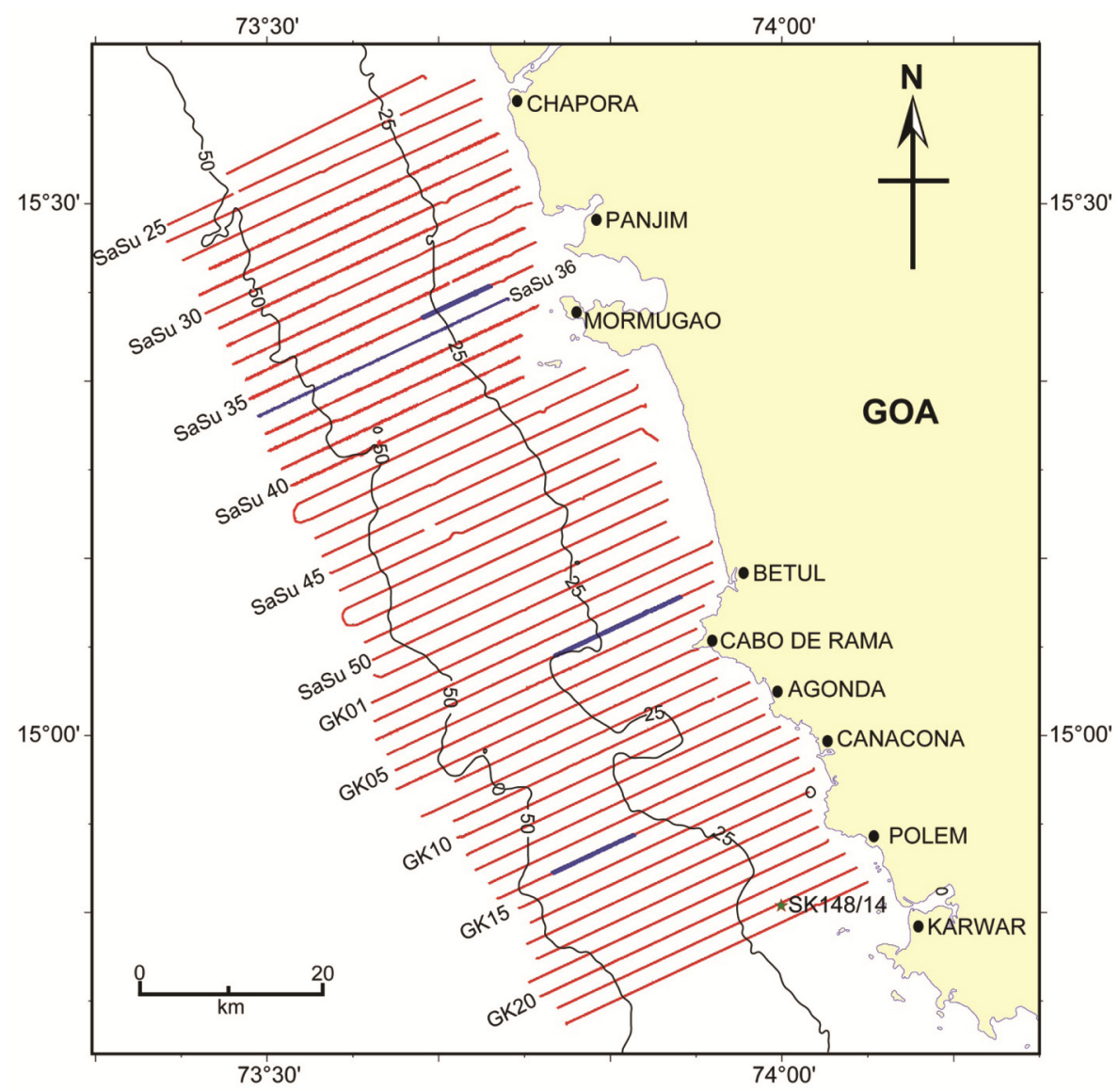

Figure 1. Map depicting study area and hinterland. Solid red lines represent seismic tracklines. Parts of the seismic tracklines, highlighted with blue colour, refer to the locations corresponding to seismic sections used in subsequent figures. Bathymetric contours $(25 \mathrm{~m}$ and $50 \mathrm{~m})$ are shown with solid black lines. Star shows location of borehole SK-148/14.

Analysis of seismic sections reveals lens-shaped sediment package comprising of low amplitude, continuous and parallel reflectors, which pinch out at $\sim 50 \mathrm{~m}$ water depth (Figure 2). The occurrence of lens-shaped sediment package in all seismic profiles makes it a characteristic feature of the study area (Figure $2 a$ ). The weak reflectors within this sediment package downlap against a transgressive surface (Figure $2 b$ ). This transgressive surface, formed due to Holocene transgression, is termed as maximum flooding surface (MFS) ${ }^{13,16}$. The Holocene MFS, overlying numerous buried channels, differentiates Holocene sediments from the Late Pleistocene sediments. From shore to $\sim 35 \mathrm{~m}$ water depth, the study area exhibits seismic signatures corresponding to rocky basement with thin layer of sediment. In this region MFS works as the boundary between rocky basement and Holocene sediment package (Figure $2 a$ ). The gas-charged sediments are often marked by reflection free patches in the HRSS sections which are caused due to absorption of seismic energy. HRSS sections from the study area revealed signatures related to gas-charged sediment. Acoustic blanking and acoustic turbidity are most abundant in the study area (Figures 3-5). In addition, gas chimneys are also ob- served at few locations. Analyses of seismic profiles reveal that the top of these reflection free patches is confined by different stratigraphic layers. On the basis of characteristic gas feature and confining layers, identified gas zones are divided into two zones, viz. zone-1 and zone-2 (Figure 6).

Zone-1 is characterized by acoustic blanking with distinct flanks (Figure 3). This zone is marked between $\sim 8 \mathrm{~m}$ and $30 \mathrm{~m}$ water depth and limited to the southern part of the study area (Figure 6). The width of acoustic blanking varies between 150 and $12,000 \mathrm{~m}$. Shallow gas features are trapped at $\sim 1.5$ to $5 \mathrm{~m}$ below sea floor (mbsf) in the Holocene sedimentary layers underlain by the MFS. Seismic profiles do not reveal any signature of gas seepage from this zone.

Zone-2 consists of several isolated small patches of acoustic blanking, acoustic turbidity and gas chimneys which are trapped at $\sim 6$ to 15 mbsf. Unlike zone-1, shallow gas features in zone-2 are mostly trapped below the MFS. These features are mostly found over the Late Pleistocene channel incision and have altered the incision signatures (Figure 4). These identified shallow gas features are either confined by river beds or by layers just 
RESEARCH COMMUNICATIONS
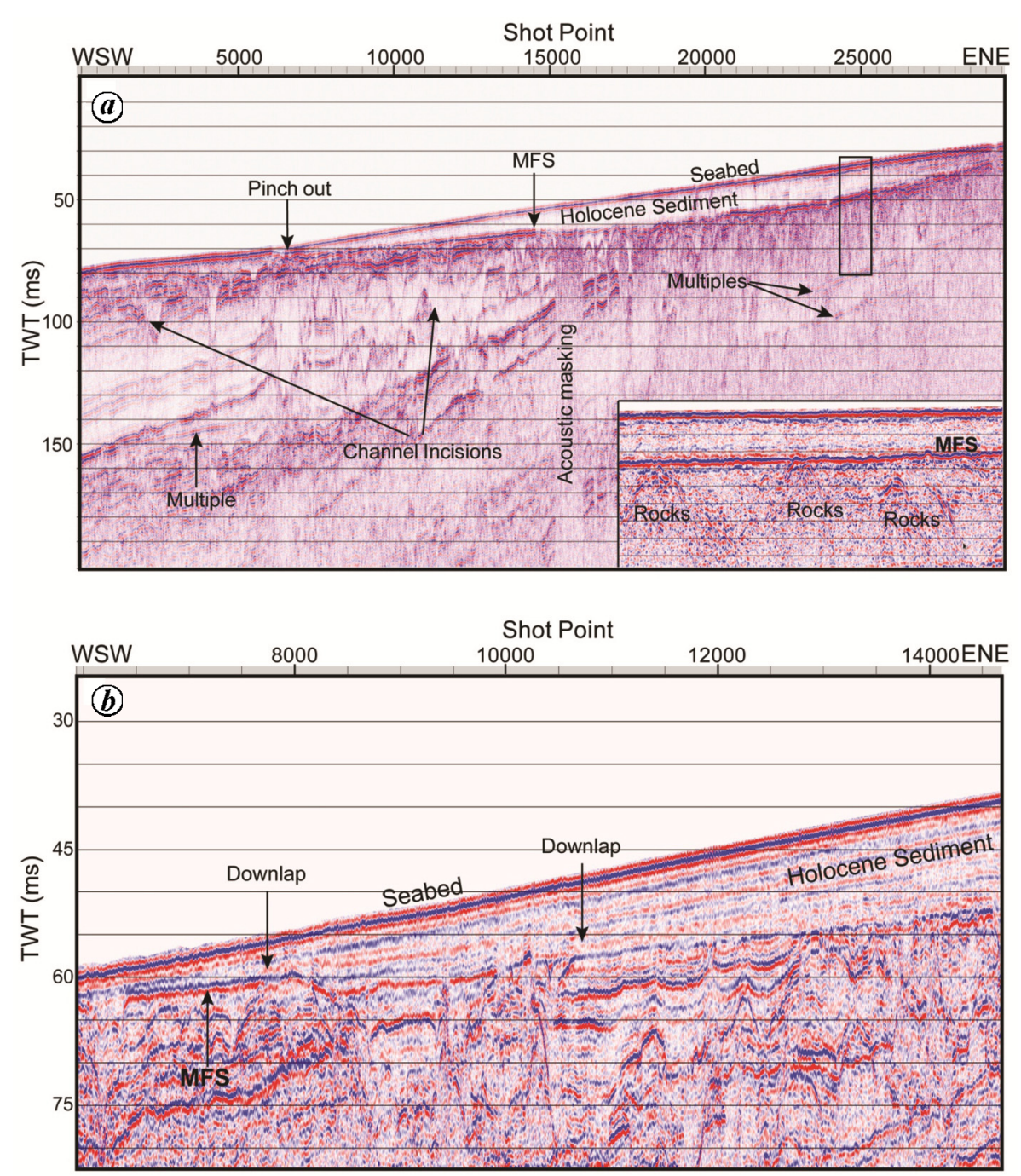

Figure 2. $\boldsymbol{a}$, Seismic sections along trackline SaSu-36, showing general characteristic of sedimentary architecture of the study area. An enlarged seismic section of the rectangular box, depicting rocky signature, is shown in lower right corner of the figure. $\boldsymbol{b}$, Seismic section along part of the trackline GK-14, showing downlapping of Holocene sedimentary strata over Holocene MFS (see Figure 1 for locations).

MFS: Maximum flooding surface.

below MFS or by both (Figure 4). Widths of shallow gas features in zone-2 vary from $\sim 120 \mathrm{~m}$ to $\sim 2500 \mathrm{~m}$ and are comparatively smaller than the zone- 1 features. Interestingly, widths of observed shallow gas features in zone-2 are always comparable or smaller than the size of river incision related to it. It may be noted that zone-1 gas features do not show any such relation with incised channel signatures. As mentioned earlier, zone-2 consists of several small patches of gas features, which are located off Chapora, Mandovi, Zuari, Colva, Sal, Talpona and Galgibag rivers. Also, zone-2 gas features are mostly confined between $\sim 20$ and $45 \mathrm{~m}$ water depths in the entire study area except near Mandovi and Zuari rivers, where shallow gas features are found beyond $\sim 50 \mathrm{~m}$ water depth (Figure 6).

From the study of HRSS profiles, it is found that the anomalous seismic reflection-free patches in the inner continental shelf off Goa appear just a few metres below the seafloor. It is found that shallow gases are trapped by Holocene layers at $\sim 1.5-5$ mbsf in zone- 1 , whereas, these are trapped below the Holocene MFS between $\sim 6 \mathrm{~m}$ and $\sim 15$ mbsf in zone-2. Trapping of these shallow gases by different stratigraphic layers reveals that the distribution and extent of the gas-charged zones are not only dependent on favourable condition such as temperature and pressure, but also dependent on the lithological character of the region.

The gas in marine sediments can originate either from biogenic or thermogenic processes ${ }^{18-21}$. The most common gas in shallow-water sediments reported globally is biogenic and is produced by microbial methanogenesis under anaerobic conditions ${ }^{22}$. In our study area, previous studies reveal that the trapped gas in the sediments is mainly methane and biogenic in nature ${ }^{13}$. Fine-grained 

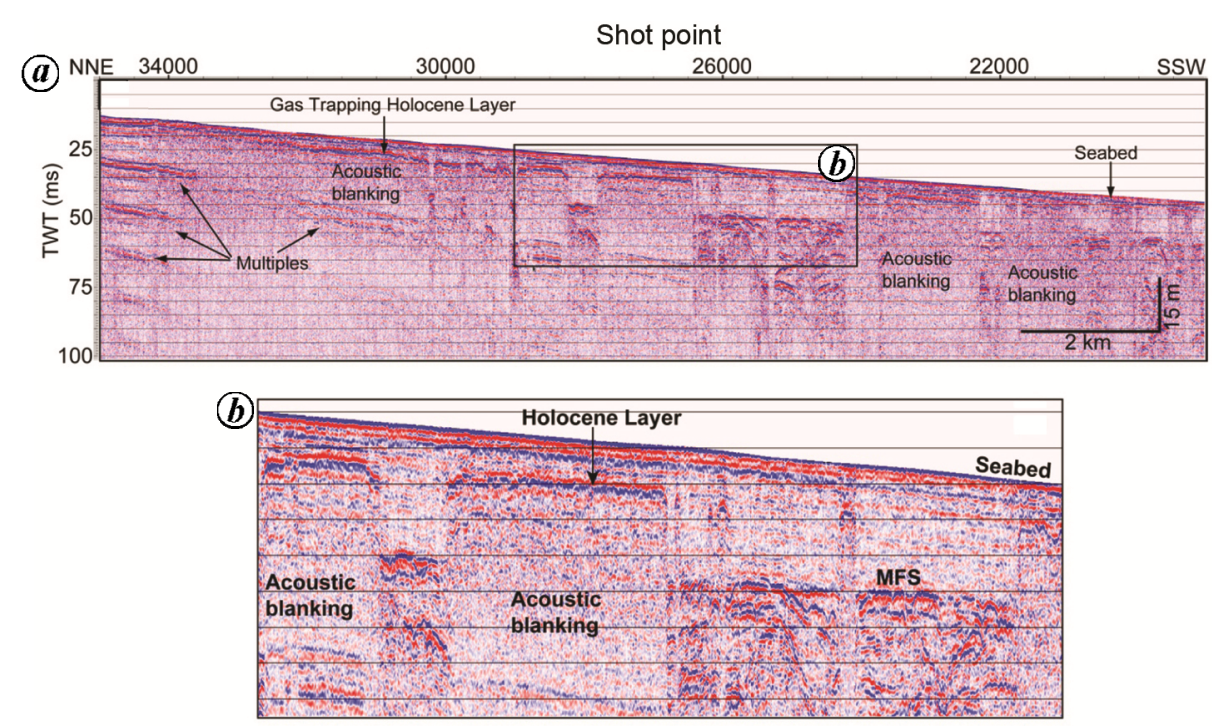

Figure 3. $\boldsymbol{a}$, Seismic sections along trackline GK-03, showing gas trapped by the Holocene sedimentary layers in zone-1 (see Figure 1 for location). $\boldsymbol{b}$, An enlarged section of the rectangular box (Figure $3 a$ ), showing acoustic blanking with distinct flanks.
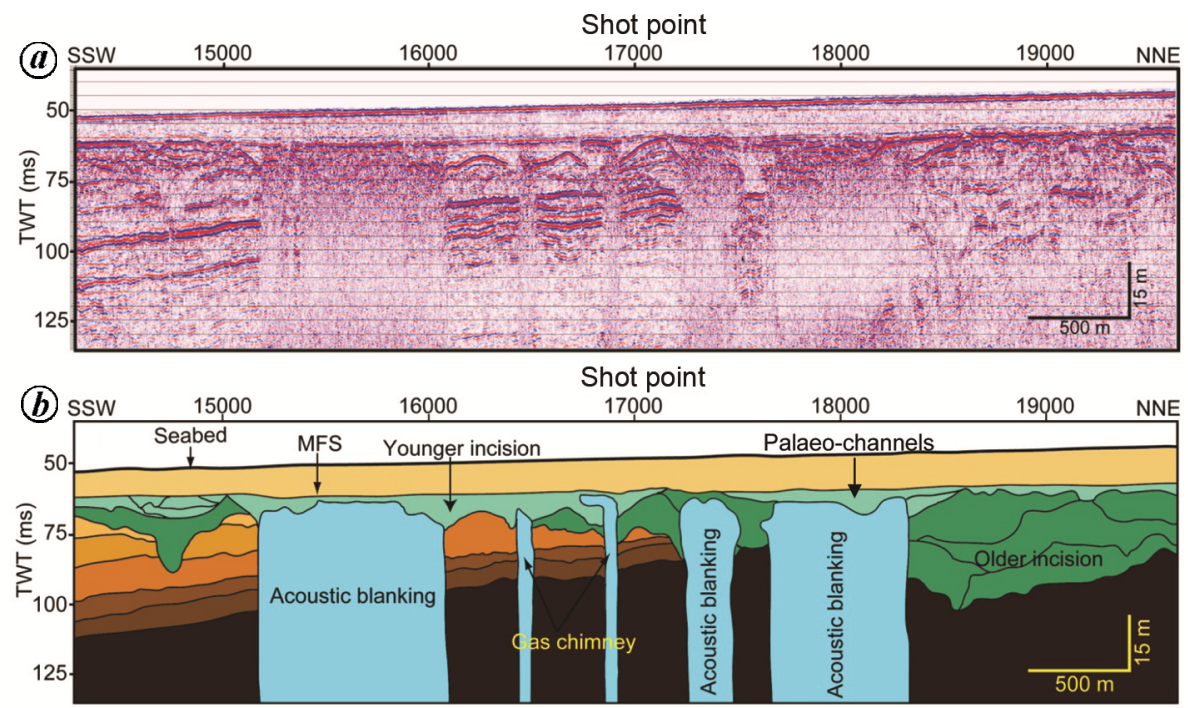

Figure 4. $\boldsymbol{a}$, Seismic section along trackline SaSu-36. $\boldsymbol{b}$, Interpreted seismic section showing gas trapped below MFS and river bed. It also depicts various seismic signatures corresponding to gas masking such as acoustic blanking and gas chimney.

muddy sediment zones that receive high fluxes of organic material provide ideal conditions for the formation of biogenic methane ${ }^{23}$. The probable sources of organic material on the inner continental shelf are: (i) intertidal vegetation (mangroves) which were buried due to the sea level rise, (ii) the terrigenous material brought by river channels through its course during the lowered sea level condition, (iii) the terrigenous materials supplied by the river channels during highstand sea level and were driven away by coastal long shore currents, and (iv) marine productivity. Since gas features in zone-1 are not linked with any channel incision, it is interpreted that the organic material which caused gas formation in zone-1, might have been derived from the buried intertidal vegetation (mangroves) and from the material carried by coastal long shore currents. Acoustic masking similar to zone-1 is not observed in the entire area. Further, limited occurrence of gas-charged sediment (zone-1) off Betul-Cancona region (Figure 6) might be due to its bay like coastline configuration. Presence of Cabo-de-Rama headland with its coast line configuration might have acted as a barrier for long shore current and made a sheltered basin for sediment deposition with low energy condition. Further, available Holocene sea level curve of the west coast of India reveals nearly stand still condition at $\sim 25 \mathrm{~m}$ below present sea level during 10,000-9,000 years BP (ref. 24). 


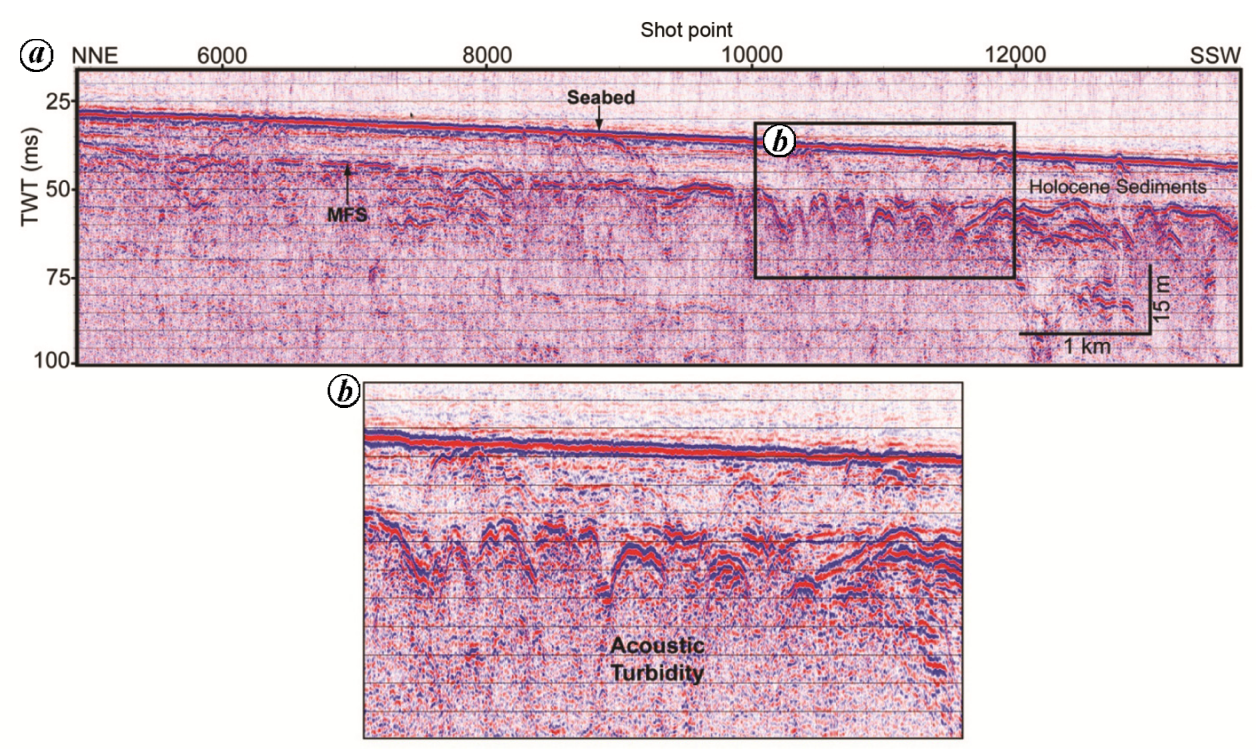

Figure 5. a, Seismic sections along trackline SaSu-35, showing acoustic turbidity. $\boldsymbol{b}$, Enlarged seismic section of the rectangular box shown in Figure 5.

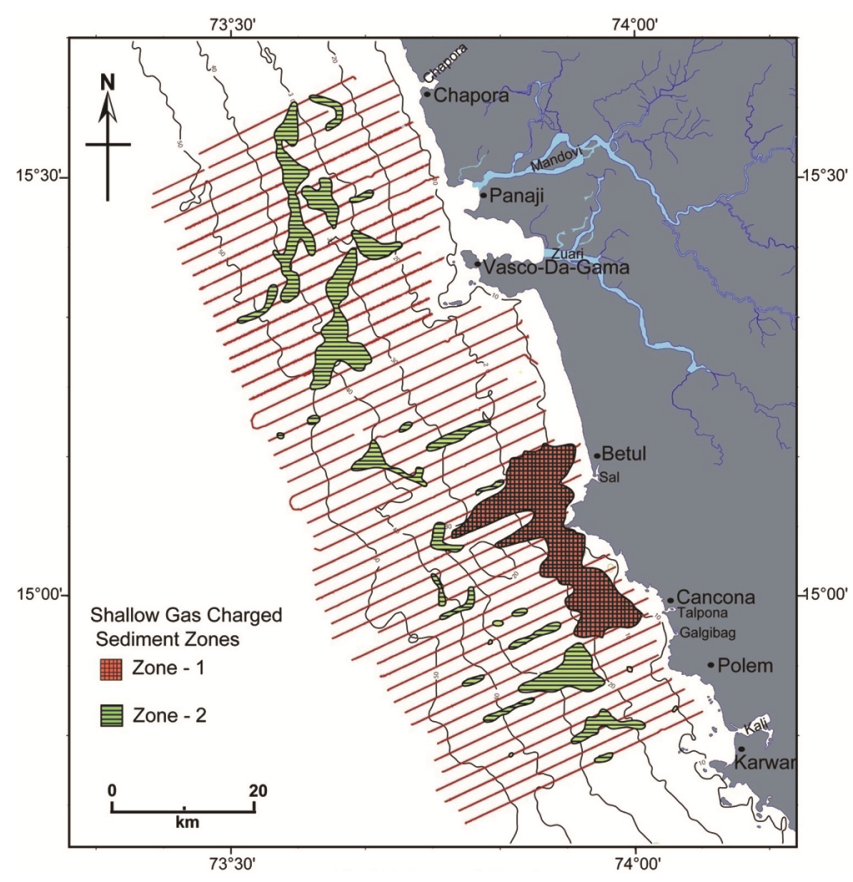

Figure 6. Map depicting shallow gas-charged sediment zones in the study area. Shaded patch with orange colour represents zone-1. Shaded patches with green colour represent zone-2. Bathymetric contours (10, $20,30,40$ and $50 \mathrm{~m}$ ) are shown with solid black colour lines.

Relatively stable sea level and gently sloping intertidal areas with suitable substrate (silt and clay) provide ideal conditions for intertidal vegetation (mangroves) ${ }^{25}$. Therefore, this period was favourable for extensive mangrove growth in the then exposed intertidal zone which is presently submerged between 20 and $30 \mathrm{~m}$ water depth. It may be mentioned here that previous studies based on sediment core analysis revealed the presence of peat within the silty substrate from several locations of shallow water region of central west coast of India ${ }^{26,27}$. Sediment core data off Goa-Karwar (SK-148/14 in Figure 1) region revealed mangrove derived peats which were formed during the early Holocene. This peat dominated layer is overlain by clay layers (sticky clay). Zone-1, where the gas is trapped within the Holocene layer above the MFS is one such zone. Therefore, source of organic material in zone-1 is interpreted to be predominantly buried mangrove remains. Cabo-de-Rama headland with its coast line configuration had provided the favourable sheltered region for preservation of mangroves during rapid sea level rise $(12 \mathrm{~m} / \mathrm{kyrs})$ between 9000 and 7000 years BP. Over a period of time, these preserved mangrove remains were converted first to peat and later became a source of gas trapped in sediments of zone- 1 .

Zone-2 consists of several isolated patches of gascharged zones. More than $90 \%$ of the observed columnar acoustic blanking and turbidity in zone-2 are found in the immediate vicinity of the lenticular channel incision. In zone-2, shallow gases are trapped mostly below MFS and buried river bed. These observations indicate that gas features in zone- 2 can be linked with channel incisions. The organic materials, brought by these palaeo-channels which are subsequently buried in the channel due to post glacial sea level rise, are the cause of it. Channel incisions are found to be carved during different low stand, half cycle of sea level associated with different glacial periods ${ }^{16}$. Therefore, it can be interpreted that the organic material responsible for these gas-charged zones was also brought by rivers during different glacial periods. In the region of gentle slopes, hydraulic energy of the river channel decreases downstream. Base level (i.e. sea level for coastal rivers) rise causes aggradations of river bed in 
the lower hydraulic energy condition. The loss in hydraulic energy of the incised river downstream with rising base level might be the reason for limited offshore extent of the zone-2, which is mostly located up to $\sim 45 \mathrm{~m}$ water depth and rarely found beyond $\sim 45 \mathrm{~m}$ water depth.

Although bathymetry of the study area does not show any signature related to gas escape through seabed, HRSS profiles at very few locations suggest gas seepage in zone- 2 of the study area. These features are related to acoustic turbidity which is mostly confined below MFS (Figure 5). In the absence of clear evidence of gas seepage, it is suggested that high resolution sonography of the seabed and chemical analysis of sediment and water samples need to be studied to ascertain seepages of gas from the seabed.

Analysis of HRSS data allowed us to mark two different types of gas-charged sediment zones on the inner continental shelf off Goa, central west coast of India. Zone-1 has limited areal extent between $\sim 8$ and $30 \mathrm{~m}$ water depth in the sheltered basin of the study area, whereas zone- 2 is distributed in the entire study area mostly between $\sim 20 \mathrm{~m}$ and $\sim 45 \mathrm{~m}$ water depth. Lithological characteristics of the Late Pleistocene-Holocene sedimentary deposits controlled the distribution of gas-charged sediment. The source organic material as well as sediments of zone-1 and zone-2, were deposited in the Holocene and Late Pleistocene respectively. The biogenic gases in zone-1 are confined within the Holocene sedimentary layers whereas they are confined in zone- 2 below the Holocene MFS within the palaeo-river bed or a layer just below MFS or by both. Gases in zone-1 were formed by organic material which was predominantly mangrove (intertidal vegetation) derived. Further, our study suggests that coastline configuration, long-term longshore current pattern, Holocene rapid sea level rise and lithological character of exposed intertidal zone had played a key role in the formation and distribution of gas-charged sediment of zone1. On the other hand, biogenic gases in zone-2 were formed by organic material which was predominantly derived by ancestral rivers through its course during different glacial periods of the Late Pleistocene. The distribution pattern of palaeo-rivers and their hydraulic energy condition during the base level rise played a key role in formation and distribution of gas-charged sediments in zone-2.

1. Hinrichs, K. and Boetius, A., The anaerobic oxidation of methane: new insights in microbial ecology and biogeochemistry. In Ocean Margin Systems (eds Wefer, G. et al.), Springer-Verlag, Berlin, Heidelberg, 2002, pp. 457-477.

2. Dekas, A. E., Poretsky, R. S. and Orphan, V. J., Deep-sea archaea fix and share nitrogen in methane-consuming microbial consortia. Science, 2009, 326, 422-426; doi:10.1126/science.1178223.

3. Boetius, A. and Wenzhoefer, F., Seafloor oxygen consumption fuelled by methane from cold seeps. Nat. Geosci., 2013, 6, 725734; doi:10.1038/ngeo1926.
4. Best, A. I., Tuffin, M. D. J., Dix, J. K. and Bull, J. M., Tidal height and frequency dependence of acoustic velocity and attenuation in shallow gassy marine sediments. J. Geophys. Res., Solid Earth, 2004, 109(B8), 101.

5. Judd, A., Davies, G., Wilson, J., Holmes, R., Baron, G. and Bryden, I., Contributions to atmospheric methane by natural gas seepage on the UK continental shelf. Mar. Geol., 1997, 137, 165189.

6. Premchitt, J., Rad, N. S., To, P., Shaw, R. and James, J. W. C., A study of gas in marine sediments in Hong Kong. Cont. Shelf Res., 1992, 12(10), 1251-1264.

7. Garcia-Gil, S., Vilas, F. and Garcia-Garcia, A., Shallow gas features in incised-valley fills (Ria de Vigo, NW Spain): a case study. Cont. Shelf Res., 2002, 22(16), 2303-2315.

8. Hovland, M. and Judd, A. G., The global production of methane from shallow submarine sources. Cont. Shelf Res., 1992, 12(10), 1231-1238.

9. Siddiquie, H. N., Rao, D. G., Vora, K. H. and Topgi, R. S., Acoustic masking in sediments due to gases on the western continental shelf of India. Mar. Geol., 1980, 39, 27-37.

10. Rao, P. S., Sonograph patterns of the central western continental shelf of India. J. Coast. Res., 1989, 5-4, 725-736.

11. Karisiddaiah, S. M., Veerayya, M., Vora, K. H. and Wagle, B. G., Gas charged sediments on the inner continental shelf off western India. Mar. Geol., 1992, 1(10), 143-152.

12. Karisiddaiah, S. M. and Veerayya, M., Methane-bearing shallow gas-charged sediments in the eastern Arabian Sea: a probable source for greenhouse gas. Cont. Shelf Res., 1994, 14(12), 13611370 .

13. Mazumdar, A. et al., Shallow gas-charged sediments off the Indian west coast: Genesis and distribution. Mar. Geol., 2009, 267, 71-85.

14. Wagle, B. G., Vora, K. H., Karisiddaiah, S. M., Veerayya, M. and Almeida, F., Holocene submarine terraces on the western continental shelf of India: implications for sea-level changes. Mar. Geol., 1994, 117, 207-225.

15. Karisiddaiah, S. M., Veerayya, M. and Vora, K. H., Seismic and sequence stratigraphy of the central western continental margin of India: late-Quaternary evolution. Mar. Geol., 2002, 192, 335-353.

16. Dubey, K. M., Chaubey, A. K., Mahale, V. P. and Karisiddaiah, S. M., Buried channels provide keys to infer Quaternary stratigraphic and paleo-environmental changes: a case study from the west coast of India. Geosci. Front., 2018; https://doi.org/10. 1016/j.gsf.2018.09.016.

17. Krishna, K. S., Rao, D. G., Murty, G. P. S. and Ramana, Y. V., Sound velocity, density, and related properties along a transect across the Bay of Bengal. Geol. Mar. Lett., 1989, 9, 95-102.

18. Floodgate, G. D. and Judd, A. D., The origin of shallow gas. Cont. Shelf Res., 1992, 12, 1145-1156.

19. Megonigal, J. P., Hines, M. E. and Visscher, P. T., Anaerobic metabolism: linkages to trace gases and aerobic processes. In Treatise on Geochemistry: Biogeochemistry (eds Holland, H. D. and Turekian, K. K.), Elsevier Pergamon, 2003, vol. 8, pp. 317424.

20. Canfield, D. E., Kristensen, E. and Thamdrup, B., Aquatic geomicrobiology. Adv. Mar. Biol., 2005, 48, 638.

21. Reeburgh, W. S., Oceanic methane biogeochemistry. Chem. Rev., 2007, 107, 486-513.

22. Judd, A. G. and Hovland, M., Seabed Fluid Flow: Impact on Geology, Biology and the Marine Environment, Cambridge University Press, New York, 2007.

23. Fleischer, P., Orsi, T. H., Richardson, M. D. and Anderson, A. L., Distribution of free gas in marine sediments: a global overview. Geo. Mar. Lett., 2001, 21, 103-122.

24. Hashimi, N. H., Nigam, R., Nair, R. R. and Rajagopalan, G., Holocene sea-level fluctuations on western Indian continental margin: an update. J. Geol. Soc. India, 1995, 46, 157-162. 
25. Woodroffe, C. D., Development of mangrove forests from a geological perspective. In Biology and Ecology of Mangroves. Tasks for Vegetation Science (ed. Teas, H. J.), Springer, Dordrecht, 1983, p. 1-17; https://doi.org/10.1007/978-94-017-0914-9 1.

26. Mascarenhas, A., Significance of peat on the western continental shelf of India. J. Geol. Soc. India, 1997, 49, 145-152.

27. Pandarinath, K., Shankar, R. and Yadava, M. G., Late Quaternary changes in sea level and sedimentation rate along the SW coast of India: evidence from radiocarbon dates. Curr. Sci., 2001, 81(5), 594-600.

ACKNOWLEDGEMENTS. The authors thank the Director, CSIRNational Institute of Oceanography, Goa for his support, encouragement and permission to publish this work. We thank the entire scientific and technical team and crew onboard Coastal Research Vessel Sagar Sukti and Mechanized Fishing Boat Phalguni for providing their support during data acquisition. Figures were prepared using GMT software of Wessel and Smith (1998). K. M. Dubey acknowledges the University Grants Commission, New Delhi, India for financial support as JRF and SRF. This is CSIR-NIO contribution number 6330.

Received 19 August 2018; revised accepted 27 November 2018

doi: $10.18520 / \mathrm{cs} / \mathrm{v} 116 / \mathrm{i} 8 / 1410-1417$

\section{Carbon sequestration potential of mango orchards in the tropical hot and humid climate of Konkan region, India}

\author{
A. N. Ganeshamurthy*, V. Ravindra, T. R. Rupa \\ and R. M. Bhatt \\ ICAR- Indian Institute of Horticultural Research, \\ Bengaluru 560 089, India
}

Cultivated grafted mangoes are not the same as polyembryonic seedling-based wild mangoes in terms of biomass production and carbon sequestration. We estimated the carbon sequestration potential of mangoes in Konkan region, which is a prime mango belt of India producing the popular Alphonso mangoes. Allometric equation developed for grafted mangoes was used to estimate tree biomass. Konkan mango belt spread over 106,210 ha sequesters $9.913 \mathrm{mt}$ of carbon. However, the carbon sequestration potential of these cultivated grafted mangoes is very low compared to polyembryonic seedling-grown mangoes in the wild. Since mangoes in the Konkan region have mostly occupied degraded lands of lateritic origin, such re-

*For correspondence. (e-mail: angmurthy@gmail.com) gions have been brought under productive mango orchards. As a consequence where forests have disappeared and mangoes have occupied the region, the carbon sequestered by them is a bonus apart from the production of mangoes. The administrators in these regions must use this information for claiming carbon credits for the benefit of farmers and the local population.

Keywords: Carbon sequestration, mango orchards, soil carbon stocks, tree biomass.

THE most dreaded problem of the new millennium caused by the impact of human activity is global warming. Anthropogenic activities like enhanced fossil-fuel consumption coupled with deforestation are causing serious public and political concerns on greenhouse gas (GHG) emissions and their consequences on loss of biodiversity and climate change $\mathrm{e}^{1-4}$. An option for augmenting the emission of GHGs is to enhance the carbon stored in perennial trees through sequestration. Forests sink about $40 \%$ of the global carbon on land ${ }^{5}$. However, perennial orchards, plantations and agro forestry are other alternatives for the trapping of carbon. It is considered that in the Indian context forests, agroforestry and perennial horticultural crops trap a significant amount of carbon emitted through fossil-fuel combustion ${ }^{6}$. The dynamics of this forest carbon has a significant influence on the global carbon budget. Estimates based on global or regional soil carbon densities of various forests shows that Indian forests sequester about 5.3-6.7 Pg C (refs 7, 8). In the present scenario, the forest area is declining while perennial fruit orchards and plantation area are on the increase ${ }^{\text {. }}$.

Generally, during the initial stage of establishment, both orchards and forests sequester similar amounts of carbon. Comparing orchards with forests is not justified as the former have a management component completely anthropogenic, while management of the latter in Asian countries is more towards silviculture and not inputbacked management. Nevertheless, orchards do have the potential similar to forests but on a lower scale because of indirect $\mathrm{C}$ emissions associated with orchard management practices. An estimate of the carbon sequestration potential of fruit orchards in India is therefore essential for any strategic planning, offsetting GHG emissions and for trading carbon.

Mango is the major fruit crop grown throughout India in areas having a distinct dry and wet season. Being an evergreen and deep-rooted (1.0 $\mathrm{m}$ and deeper) tree, it has adopted to fix carbon under large seasonal variation of light and water. Two types of mango population occur in India, the wild polyembryonic mangoes and the cultivated grafted mangoes. Estimates of the population and area occupied by wild polyembryonic mangoes are not available, but surely is a sizable area as India is the origin of mangoes. Cultivated mango occupies an area of nearly 